\title{
Hilasterion and imperial ideology: A new reading of Romans 3:25
}

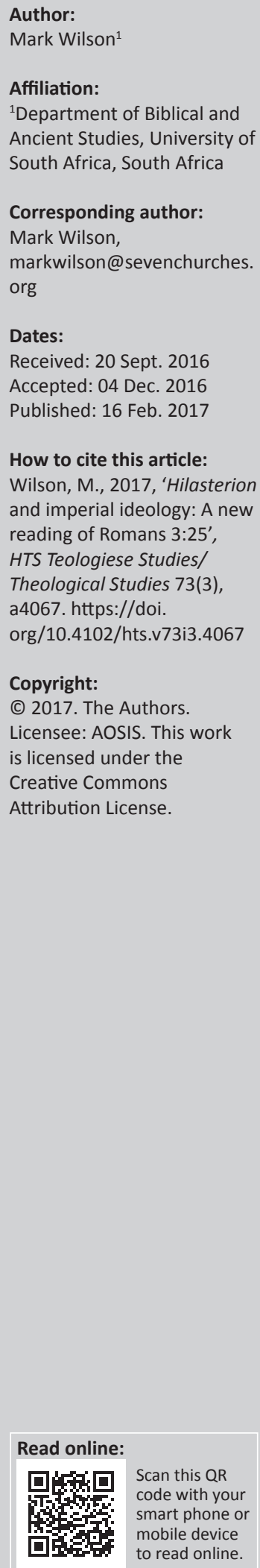

Paul uses the hapax legomenon í $\alpha \sigma \tau$ ๆ́pıv in Romans 3:25. Pauline scholars have discussed the background for Paul's use of the word, whether from the LXX, Second Temple practice or pagan inscriptions. Two altars were found in the Asian city of Metropolis in the early 1990s

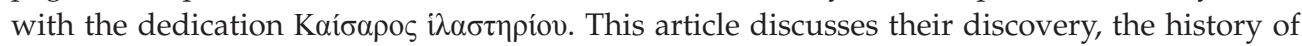
Metropolis and the possible relationship of Paul to the city. It explores the date of the erection of the altars by establishing a viable sitz im leben early in the reign of Augustus. It then traces the semantic history of the i $\lambda \alpha \sigma \tau$ íprov and attempts to establish its possible meaning within Pauline theology. Finally, the question whether i $\lambda \alpha \sigma \tau \eta$ prov should be added to the vocabulary of imperial ideology in Paul's writings is addressed.

\section{Introduction}

The words of Chaniotis (2012:320) are prescient for our topic when he writes that 'progress in the understanding of early Christianity is exclusively based on papyri and inscriptions'. The discovery of two altars in the Graeco-Roman city of Metropolis in the early 1990s and their subsequent publication in 2006 has gone largely unrecognised by New Testament scholars. The altars date

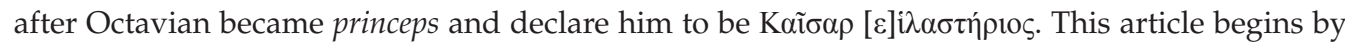
discussing the location and history of Metropolis before elucidating the archaeological discovery of the two altars and their subsequent epigraphic publication. It then addresses the historical situation in the Roman Empire that brought about the erection of such imperial altars, especially in the province of Asia. Next it discusses Paul's probable relationship with Metropolis located between Ephesus and Smyrna. The semantic history of the i $\lambda \alpha \sigma \tau \eta \dot{\rho}$ iov is traced, and the status quaestionis of Paul's use of i $\lambda \alpha \sigma \tau$ prov in Romans 3:25 is then reviewed briefly. Finally, it discusses whether i $\lambda \alpha \sigma \tau$ fív may be an imperial term and how Paul might have redeployed the imperial ideology of Caesar as reconciler into his discussion of Christ's redemptive work in Romans.

\section{Metropolis's location and history, and the arrival of Christianity}

Metropolis faced east toward the north-western shore of Pegaseum Stagnum, a small lake or marsh from which a stream called the Pyrites flowed south into the ancient Cayster River (Küçük Menderes) above Ephesus. ${ }^{1}$ The city was located $30 \mathrm{~km}$ north of Ephesus and $40 \mathrm{~km}$ south of Smyrna, ${ }^{2}$ almost midway between these two metropoleis of Asia. It was just north of a junction for a road that led from Ephesus to Sardis via Hypaipa (Figure 1). ${ }^{3}$

The city was founded during the Ionian colonisation of western Asia Minor around 725 BCE. Pottery finds on the acropolis show occupation during the Archaic Period, although there appears to be a hiatus in the settlement history during the Classical Age. After Alexander's arrival in $334 \mathrm{BCE}$ and the founding of cities in western Anatolia during the Hellenistic period, Metropolis shows development in its city plan (Figure 2). It later fell under the jurisdiction of the Attalid Empire based in Pergamum and then under the Romans when Attalus III bequeathed his kingdom to Rome in 133 BCE. When the province of Asia was formed in 129 BCE, Metropolis was given free city status and the right to mint its own coins. Located in the conventus of Ephesus, it joined other Ionian cities in the rebellion of Mithridates against the Romans in 86 BCE. With the coming of the Pax Romana under Augustus, the city flourished. The theatre and bouleuterion were restored, a gymnasium was presided over by a woman named Augusta,

1.Pliny Nat. 5.31. Today the site is located between the villages of Yeniköy and Özbey near Torbalı at the base of a mountainous ridge called Koçkadın and Alaman Dağı. The Barrington Atlas (2000) localises Metropolis on Map 56 but omits it on Map 57.

2.Strabo (14.1.2) incorrectly gives the distance to Ephesus as 120 stadia (22.2 km)

3.A Hellenistic milestone found along this route near Mehmetler now stands in the Ephesus Museum in Selçuk. It marks the distance as 90 stadia to Ephesus, and 410 stadia to Sardis (French 1997:191-194). 


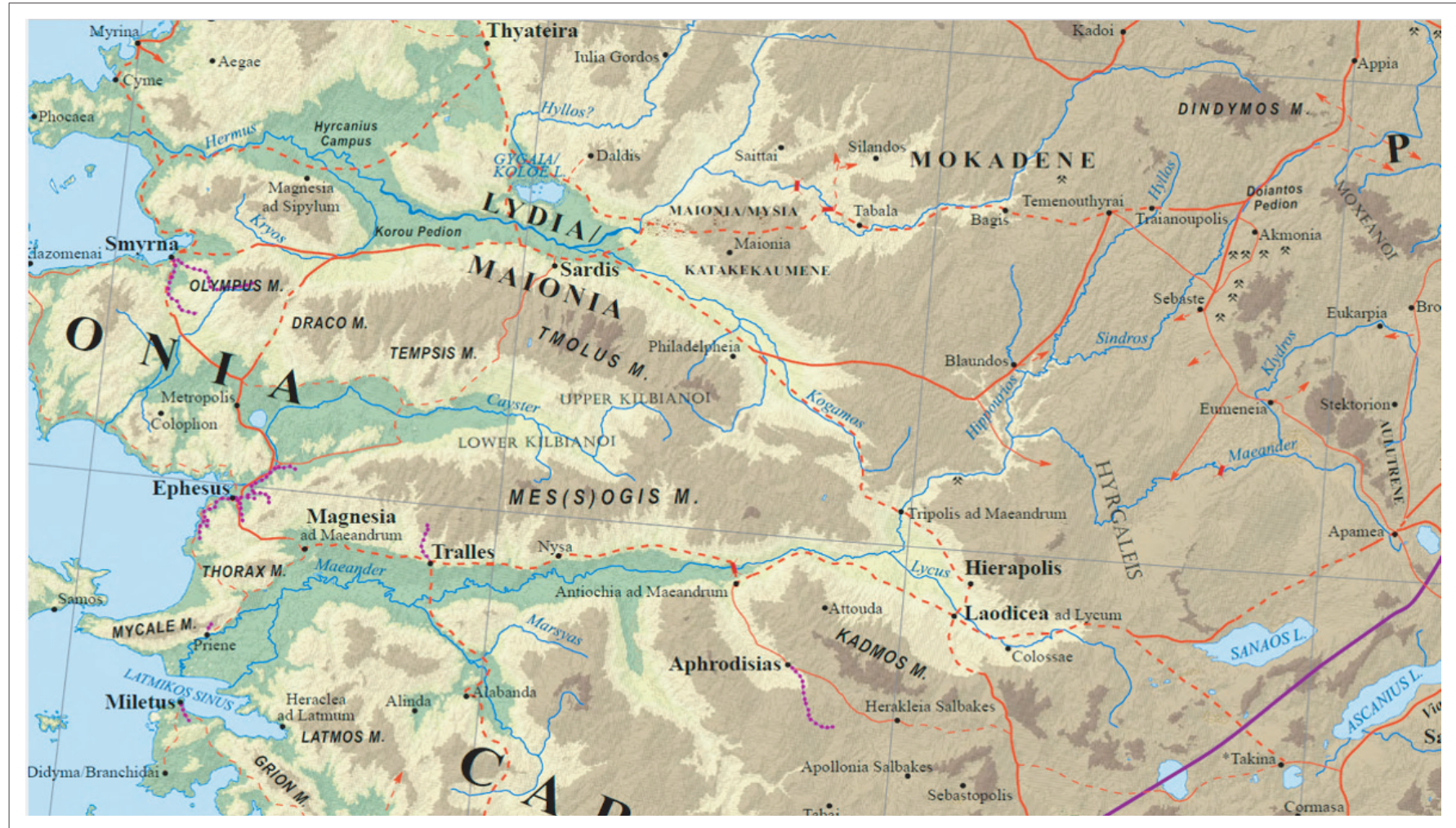

Source: Courtesy of Princeton University Press

FIGURE 1: Map of Asia with Metropolis.

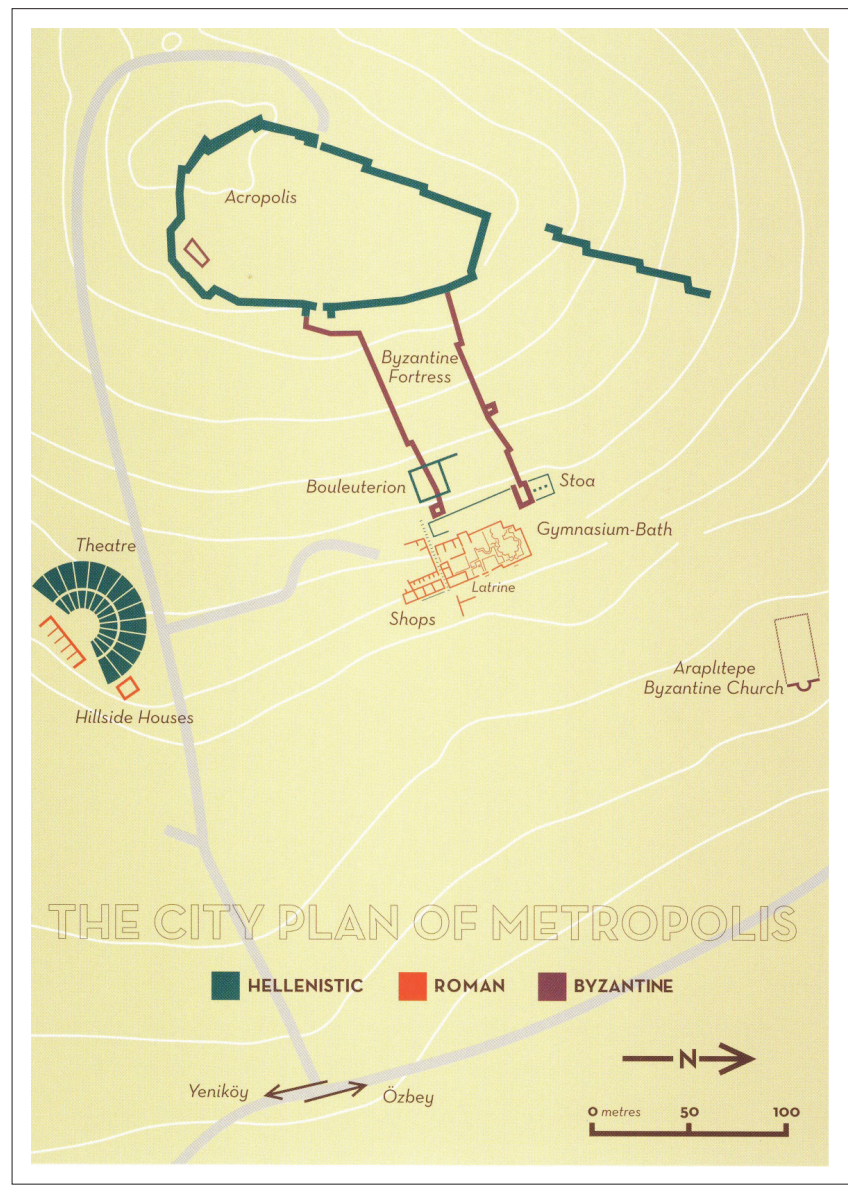

Source: Courtesy of Sabancı University Press

FIGURE 2: City plan of Metropolis. and Roman culture became entrenched in the city. Meriç (2004:66-67) suggests that the city must have been affected by the great earthquake that struck western Asia Minor in $17 \mathrm{CE}$ and then, unable to recover, entered a period of stagnation until the reign of Trajan. ${ }^{4}$ However, Metropolis is not named among the 12 Lydian cities destroyed by the earthquake, and to those cities affected, principally nearby Sardis, Tiberius granted not only tax relief but also gave 10 million sesterces in aid for rebuilding. ${ }^{5}$ An earthquake did strike Ephesus in $23 \mathrm{CE}$; so perhaps this was the earthquake that damaged Metropolis, but no aid was given this time. The archaeological record shows that under Trajan the minting of coins resumed in Metropolis, and damaged buildings were repaired as well as new construction commenced.

Because of Metropolis's location on the main road between Ephesus and Smyrna, it is likely that the gospel arrived at an early date. Schnabel (2004:2.1203) suggests that Metropolis lay along the route of Paul's third journey as he

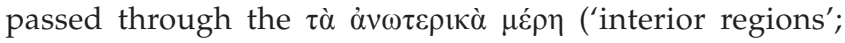
NLT, ESV, cf. NIV) to come to Ephesus (Ac 19:1). ${ }^{6}$ However, the route following the course of the Cayster River did not 4.Pliny (2.86.200). In chapter one, Meriç (2004:25-79) provides a complete history of the city. For more on the city's history, see Aybek et al. (2009:40-61).

5.Tacitus (Ann. 2.47). Jerome (Chron. 199.2) in his translation of Eusebius's Chronicle mentions Ephesus among the cities destroyed. If this were the case, Metropolis was probably affected too.

6.In this opinion, Schnabel follows Ramsay (1898:3.866) who writes that Paul took another more direct road 'across High Phrygia, keeping very near a straight line from Metropolis to Ephesus'. However, this is a different Metropolis, the one near Synnada not Ephesus. 
pass through Metropolis but diverted south of the marshy Pegaseum Stagnum, as the Barrington atlas shows (Talbert 2000:61). So Schnabel's suggestion is unlikely, especially given that Paul's route from Apamea was more likely through the shorter and easier Meander valley. ${ }^{7}$ Paul during his 3 years stay in Ephesus perhaps travelled to neighbouring cities such as Metropolis, thus prompting Luke's claim that the word had spread widely in Asia (Ac 19:10, 20). As Ramsay (1994) stated about Revelation's seven churches:

It may also be regarded as practically certain that the great cities which lay on the important roads connecting those seven leading cities with one another had all 'heard the word'. (p. 125)

Metropolis was among those cities on an important road, so it is possible that Paul had a relationship with the believers there. After the riot forced Paul to leave Ephesus, the land route would have taken him through Metropolis again on his way up the coast to Troas (Ac 20:1-2; 2 Cor. 2:12).

\section{Discovery of the altars at Metropolis's theatre and bouleuterion}

In 1990, archaeologists from Doküz Eylül (9 September) University in Izmir began to excavate the theatre of Metropolis. In front of the orchestra, three round altars were found in situ (Figure 3). The excavators describe them: 'The altars are ornamented with bull's head, ram and deer heads among which grapes, pomegranate, pine cones and embellished garlands are placed' (Aybek, Meriç \& Öz 2009:75). ${ }^{8}$ The one on the left (facing the cavea) was dedicated to Germanicus and dates between $4 \mathrm{CE}$ and $19 \mathrm{CE}$,

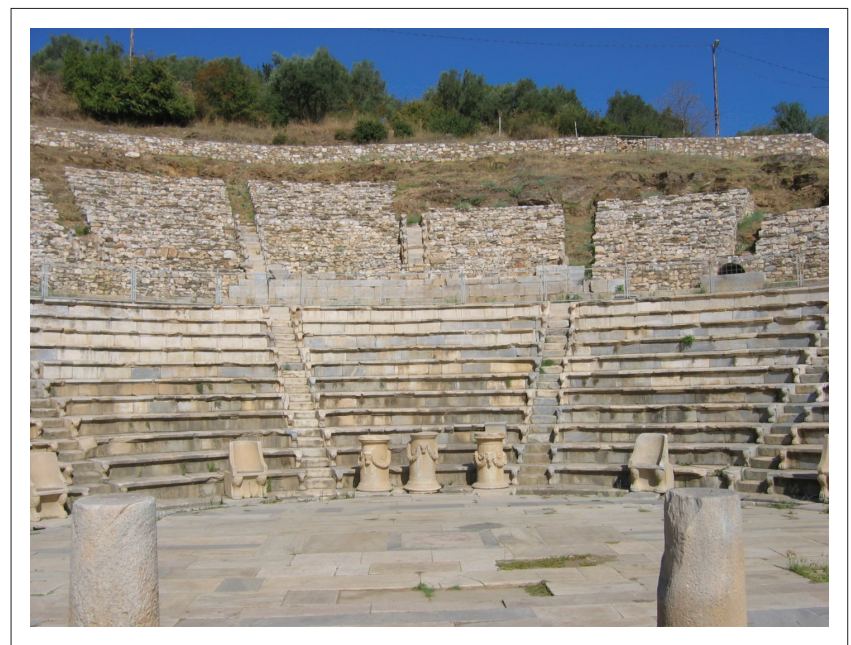

Source: Courtesy of Cenk Eronat

FIGURE 3: Altars in situ in theatre.

7.The main objection to this route is that Paul wrote in Colossians $2: 1$ that the believers in the Lycus valley had never met him personally. This is easily answered: these churches were started later during Paul's time of ministry in Ephesus.

8.A photograph of the altars being unearthed appears on page 76 . For additional photographs, refer to Meriç (2004:86-87). while the other two altars were dedicated to Augustus. ${ }^{9}$ The altar at the right will be discussed later. The inscription

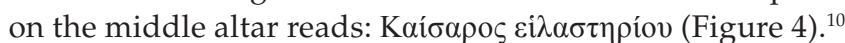
During excavations at the nearby bouleuterion in 1992, a matching altar was found with the inscription Kaí $\alpha \rho \circ$

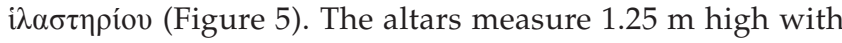
a top diameter of $65 \mathrm{~cm}$. These two Augustan altars are of special interest because Paul's use of the noun form i $\lambda \alpha \sigma \tau$ ๆ́p in Romans 3:25 is a hapax legomenon in the Pauline corpus with Hebrews 9:5 being the only other usage in the New Testament. The inscriptions also provide the earliest

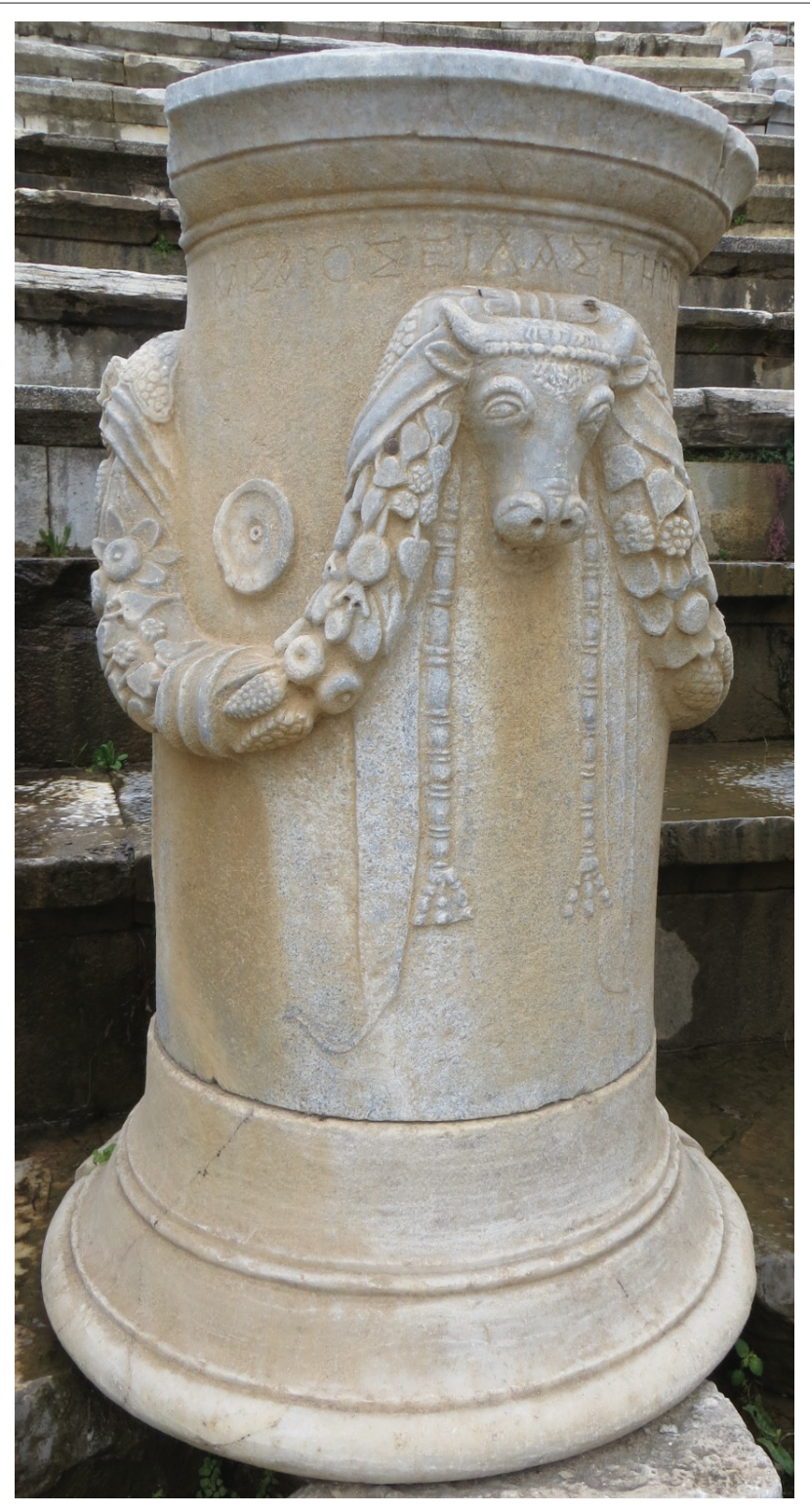

Source: Author's own work

FIGURE 4: Caesar altar from theatre.

9. For the Germanicus altar, see Chaniotis et al. (2005:1235); for the Caesar theatre altar, see Chaniotis et al. (2006:1234); and for the Caesar bouleuterion altar, see Chaniotis et al. (2005:1260). The entry for \#1260 states mistakenly that it was found in the theatre. Also, the inscription is not found in the Izmir Archaeology Museum but in the Izmir Museum of History and Art (inv. no. 21515). For a photograph of the bouleuterion altar, see Meriç (2004:116)

10.The use of the epsilon is an example of iotacism (or itacism) here in Asia Minor (see McLean 2002:349 esp. note 20). 


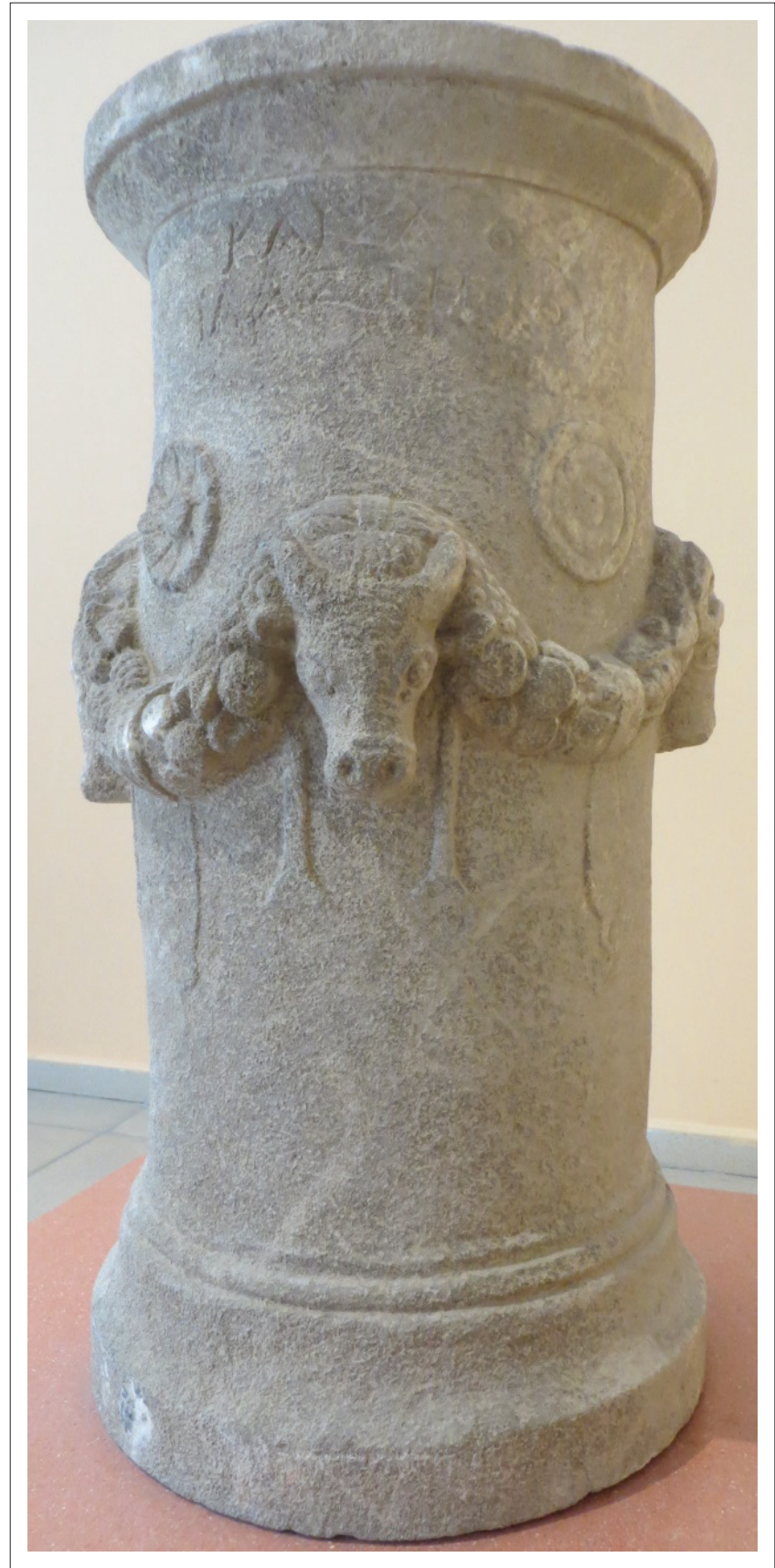

Source: Author's own work

FIGURE 5: Caesar altar from bouleuterion.

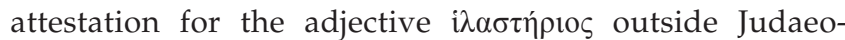
Christian literature. My own interest in these inscriptions began in the summer of 2014 after reading about them in Cooley and Salway's (2012:199) summary of inscriptions found in Asia Minor during the 1990s. ${ }^{11}$

\section{Dating of the altars}

After Augustus introduced the Pax Romana, a building revival began in Metropolis. Meriç (2004:66) writes: 'The theatre and bouleuterion were renovated, new altars were

11.In the spring of 2015 , i learned that the German scholar Alexander Weiß had also begun to research and write on these inscriptions. Professor Weiß graciously provided me with his paper as well as notes and PowerPoint presentation from a lecture given at the University of Sydney in 2014, allowing me to quote from them for this article. erected and the foundation of both public buildings was covered with marble plates'. Nevertheless, his closest estimate for the erection of these altars dates from $27 \mathrm{BCE}$ to $14 \mathrm{CE}$, the reign of Augustus (Meriç 2004:91, 116). Yet their history seems to precede this dating. Antony and Cleopatra spent the winter of 33-32 BCE in Ephesus ensuring that the province of Asia was firmly in their camp (Plutarch Ant. 56.1). However, the tide turned in 31 BCE, and Octavian defeated Antony decisively at Actium. In 30 BCE, Antony and Cleopatra committed suicide in Egypt after the fall of Alexandria. After Actium, Octavian made brief visits to Asia including Samos and Ephesus during which these communities that had formerly supported Antony now made peace with their new ruler (Cassius Dio 51.4.1). ${ }^{12}$ Antony's excessive levies had caused great economic distress in Asia. So Octavian did not punish the cities with any further penalties, apart from Kos perhaps (Magie 1950:1.441). Thus, Punt (2012:3) writes, 'After the civil war, Augustus was often upheld as herald of peace to the Empire and the world at large'.

On 13-15 August 29 BCE, Octavian was awarded a triple triumph by the Senate, which he proudly described in the Res Gestae: 'three times I have driven triumphal chariots' (Cooley 2009:121). Such honours were not only bestowed in Rome but also in the provinces. As Philo writes (Legat. 149-150; Yonge transl.):

the whole of the rest of the habitable world had decreed him honours equal to those of the Olympian gods. And we have evidence of this in the temples, and porticoes, and sacred precincts, and groves, and colonnades which have been erected ...

The physical setting where the emperor was honoured was generally in the city centre and integrated into its religious, political and economic life (Zanker 1990:298). Goldsworthy (2014:192) observes that 'communities were eager to parade their loyalty by worshipping the Roman leader himself'. In $29 \mathrm{BCE}$, the koinon of Asia received permission to build an imperial cult temple in Pergamum while in Ephesus a sanctuary dedicated to Dea Roma and Divus Julius was erected for its Roman residents (Dio Cassius Hist. Rom. 51.20.6-7). Denarii issued in Ephesus in 29-27 BCE depict Octavian on the reverse standing in a decorated quadriga, while on the obverse Victory stands on a ship's prow holding a palm and wreath. A golden aureus, likely minted in Ephesus in 28 BCE during Octavian's sixth consulship, shows him on the reverse seated in a magistrate's chair holding a scroll in his right hand, and on the ground to his left is a document box. Its inscription reads: LEGES ET IURA P(ublicae) R(ei) Restuit; 'he restored laws and rights to (or of) the res publica' (Galinsky 2012:62-63). Octavian's victory is thus portrayed as the restoration of the republic to the people of Rome, which implies reconciliation with his supporters as well as

12.In the winter of $31 \mathrm{BCE}$, an embassy from Rhosus met Augustus in Ephesus and offered him a crown and various honours. See IGLS III, no. 718; also see Sherk (1969: no. 58, iii). 
his former enemies. ${ }^{13}$ The erection of these altars in Metropolis then was part of an empire-wide expression whereby hundreds of cities around the Mediterranean erected altars and temples to Augustus at this time (Zanker 1990:304). As Weiß (2014b:3) notes, 'These altars shed some new light, perhaps not necessarily on the intentions of the victor, but certainly on the perception of the victor'.

Earlier, it was mentioned that a third altar was found in the theatre, whose style and lettering resembled the two i $\lambda \alpha \sigma \tau$ ṕpıৎ inscriptions. Its formulaic titulature for Augustus

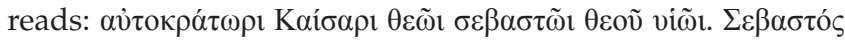
is the Greek translation of the Latin 'Augustus', a title bestowed on Octavian in January 27 BCE. Writing about an Ephesian inscription from this period, Jones (1999:90) states that the "the absence of "Augustus" from his titulature provides a terminus ante quem of $27^{\prime} \cdot{ }^{14}$ For this reason, the third altar can be dated after 27 BCE. Because the two i $\lambda \alpha \sigma \tau$ ípıৎ altars do not bear the later Augustan language, Weiß (2014b:3-4) suggests that they should be dated to the brief period after the autumn of 31 BCE but before January 27 BCE. Using the chronology outlined above, dating for the erection of the altars could possibly be narrowed further between August 29 and January 27 BCE. ${ }^{15}$

\section{Caesar as reconciler}

After Octavian was victorious over Antony at Actium, the politics of reconciliation began in the empire, especially in the Greek east. In Res Gestae 3, Augustus portrays himself as a victor merciful to citizens requesting a pardon. ${ }^{16}$ Cooley (2009:117) observes: 'His actions after Actium arguably demonstrated a degree of clemency: even a hostile account admits that he did spare some Antonians (Dio Cass. 51.2.4)'. Engelmann and Dreyer (2006:174) note similarly: 'Nach seinen militärischen Erfolgen hatte Augustus versucht, die Gräben zu überwinden, welche ein langer Bürgerkrieg aufgeworfen hatte, und seinen Gegnern die Hand zur Versöhnung gereicht'. ${ }^{17}$ Such acts are consistent with the dictates of imperial ideology, as 'the

13.Dreyer and Engelmann (2006:174) similarly write: "Der Wille und die Fähigkeit des Augustus, eine tief gespaltene Gesellschaft zu versöhnen, war eine entscheidende Voraussetzung eines friedvollen Neubeginns' (English translation: 'The will and the ability of Augustus to reconcile a deeply divided society was a crucial prerequisite for a peaceful new beginning')

14.Benjamin and Raubitschek (1959:71), in their discussion of an Augustan altar from Thera, similarly ascribe significance to this title for dating: 'The omission of the name Augustus shows that this altar belongs to the period before 27 B.C.'.

15.While this dating scenario seems likely, the extended dating up to 14 CE by the Turkish archaeologists suggested that an alternative date should be explored. The best possibility seemed the recovery by Augustus in 19 BCE of the Roman standards lost at Carrhae to the Parthians in 29 BCE. This triumph of diplomacy is mentioned by Augustus himself (Res Gestae 29.2), by Suetonius (Aug. 22), and on coin issues declaring Armenia recepta and Parthi recuperatis. But could this latter scenario better fit the historical context of the Metropolis inscriptions? The Augustan scholar Karl Galinsky gave this answer: Reconciliation/Versöhnung/Entsühnung fits the end of the civil wars much better than the settlement with the Parthians, which was resoundingly styled as 'victory' (cf. the coins with the grovelling Parthian king, the victorious return of the Roman standards to the Temple of Mars Ultor in the Forum he was building, etc.). Nowhere in the sources is there a reference to the kind of semantic complex that hilasterios and its cognates connote. That, to me, seems to be the more serious problem (personal correspondence $25 / 7 / 2015$ ).

16.The verb in the Greek version of the Res Gestae is $\dot{\phi} \phi \varepsilon$ เod $\mu \eta \eta$. With the similar

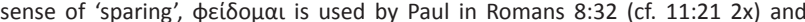
spoken by Paul in his speech to the Ephesian elders in Acts 20:29.

17.English translation: 'After his military successes Augustus tried to overcome the chasm which had produced a long civil war and had offered his opponents the hand of reconciliation'. Chaniotis et al. (2006:404) echo this judgment: 'The inscription refers to Augustus' policy of reconciliation after Actium'. sovereign's occasional exercise of mercy ... redounds to the personal glory of the sovereign, demonstrating his power and beneficence' (Elliott 2008b:87).

A further aspect of the same policy was to promote the cult of abstractions linked with the emperor. In parading the blessings conferred by his rule, abstractions played an important role in keeping the image of Augustus before the attention of the public. First and foremost were his personal virtues-valour, clemency, justice and piety-inscribed on the golden shield he received in 27 BCE (Res Gestae 34.2). ${ }^{18}$ As Fishwick (2014:50) notes, 'Other abstractions, more properly blessings rather than virtues, began their career in the period immediately following: Victoria Augusta, Pax Augusta, Concordia Augusta, perhaps also Augustan Salus, Fortuna and Felicitas'. Augustus was careful to allow only certain practices in the public cult of the state, one of which was the erection of altars that celebrated the divine virtues of his actions (Scheid 2009:292). Horace (Ep. 2.1.15-16) writes later about 12 BCE: 'We bestow the fullest honours on you who are present, and we set up altars by which to swear by your numen'. The altars erected at Metropolis thus line up with imperial practice. However, they were not erected because of an official order but evidence a local perception of a virtue of Octavian.

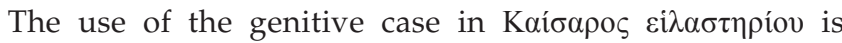
a well-known elliptical construction in epigraphical texts wherein the genitive requires a subject, in this case o ßouós, 'the altar' (Weiß 2014b:3). The likely meaning of i $\lambda \alpha \sigma \tau$ ๆ́pı (2014a:302), is versöhnend [conciliatory], and therefore they are consecrated to Octavian as the versöhnenden Caesar [reconciliatory Caesar]. Dreyer and Engelmann (2006:174) offer the translation: '(Altar des) Caesar, der die Versöhnung bringt', hence '(Altar of) Caesar, the bringer of reconciliation', or in their (2006:173) caption of its photograph: Die versöhnende Kraft Caesars [The reconciling power of Caesar]. An alternative English translation might be 'the reconciling Caesar' or 'Caesar who brings reconciliation'.

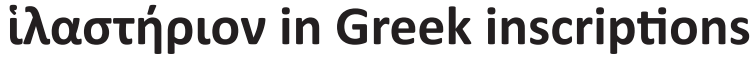

i $\lambda \alpha \sigma \tau$ ṕp appears on six inscriptions from the Roman imperial period on two islands once part of Asia. Four come from Kos and the other two from Lindos on Rhodes. Bailey (2000:156-157) observes that the pagan understanding in the 1st century CE of i $\lambda \alpha \sigma \tau$ ípเov was 'propitiatory gift' or 'votive offering' whose lexical equivalent was do $v \alpha \dot{\theta} \theta \mu \mu{ }^{19}{ }^{19}$ The six inscriptions are discussed in detail by Weiß (2014a:296-298), who demonstrates that they all arise from a Graeco-pagan context rather than from a Jewish biblical and theological worldview. Rejecting an interpretation of Schreiber (2006), Weiß (2014a:301) concludes that: 'Schreibers Interpretation ist somit philologisch nicht moglich und sein Versuch, die Rede vom

18. For a picture of the copy of this shield found at Arles with the Latin text virtutis clementiae iustitiae pietatis, see Cooley (2009:267).

19.Bailey's article is a summary of his 1999 doctoral thesis at Cambridge called 'Jesus as the mercy seat: The semantics and theology of Paul's use of hilasterion in Romans $3: 25^{\prime}$ 
"Suhnetod Christi" mittels einer Neuinterpretation von hilasterion in Rom 3,25 als "Weihegeschenk" zu uberwinden, nicht gegluckt'. ${ }^{20}$ Thus, these few contemporaneous polytheist inscriptions are not helpful in understanding either the inscriptions on Metropolis's altars or Paul's use of the word in Romans 3:25.

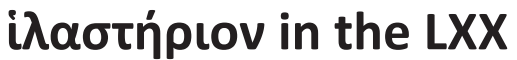

i $\lambda \alpha \sigma \tau$ frov is used 28 times in the Septuagint, with the majority found in the Pentateuch-Exodus (13x), Leviticus (7x) and Numbers (1x). These all refer to the atonement cover on the ark of covenant upon which the sacrificial blood of bulls and goats was placed (Lev 16:14-15). The five references in Ezekiel refer to the altar in the eschatological temple (Ezek $43: 14,17,20)$. Only in 4 Maccabees 17:22 does i $\lambda \alpha \sigma \tau$ ஸ́pıov refer not to a sacrificial object but to the atoning sacrifice itself. In their entry for i $\lambda \alpha \sigma \tau$ ๆ́pıv, Lust, Eynikel and Hauspie (2004:611-612) provide two main glosses: 'lid of the ark of the covenant' and 'propitiation'. Jewett (2007) helpfully summarises:

that in the LXX it refers either to the gold place on the ark of the covenant above which the indivisible presence of God was thought to hover and where blood was sprinkled on the Day of Atonement, or to purification, propitiation, and expiation in a more general sense. ${ }^{21}$ (p. 284)

Aitken (2014:205) has focused scholarly attention on the significance of inscriptions for obscure words in the Septuagint: 'Certainly, the omission of inscriptions from scholarly discussions has been common, and their full value will only be appreciated once they have been sufficiently included'. Hopefully, the Metropolis inscriptions will find their way into future discussions of the vocabulary of the LXX.

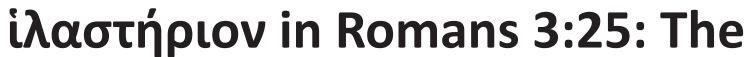 status quaestionis}

The twofold perspective just summarised by Jewett is reflected in two major lexica of New Testament Greek. Bauer et al. (2000:93) state that i $\lambda \alpha \sigma \tau$ ๆ́prov means either 'expiation' or 'place of expiation' citing Romans 3:25 and Hebrews 9:5. Friberg, Friberg and Miller (2005:ad loc) state that i $\lambda \alpha \sigma \tau \eta \dot{p}$ focuses:

on the means by which sins are forgiven having atoning power,

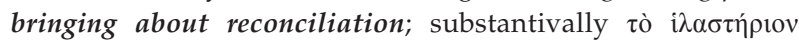
means of forgiveness (RO 3.25); by metonymy, with a focus on the place where sins are forgiven by means of the blood from an atoning sacrifice placed there place of forgiveness (italics theirs; bold mine).

As mentioned earlier, Paul's only use of i $\lambda \alpha \sigma \tau \eta \dot{\rho} \rho \mathbf{v}$ was to the

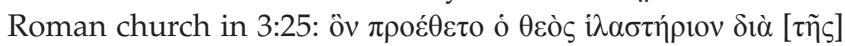

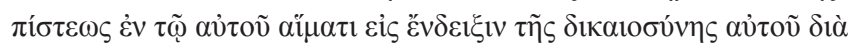

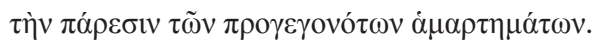

20.English translation: Schreiber's interpretation is thus philologically impossible, and his attempt to overcome the language of the 'atoning death of Christ' with reinterpretation of hilasterion in Rom 3:25 as 'consecration gift', is not successful.

21.Jewett's note 49 provides a bibliography of key sources that have extensively investigated this text.
The literature on Paul's use of i $\lambda \alpha \sigma \tau$ prov in this verse is considerable; so the state of discussion can only be briefly summarised. For a background, Bailey (2000) appeals to Exodus 15 because of Paul's reference to the Law and the Prophets in 3:21, stating:

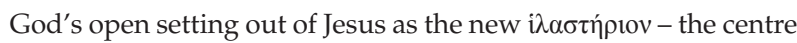
of the sanctuary and focus of both the revelation of God (Ex. 25:22; Lv. 16:2; Nu. 7:89) and atonement for $\sin$ (Leviticus 16) fulfils this tradition. (p. 157)

Thus, the concept of Jesus as 'mercy seat' is more compatible with the lexicography of the LXX and against Greek inscriptional usage. Paul's theological application of this word would not be unprecedented, because Philo (Mos 2.96)

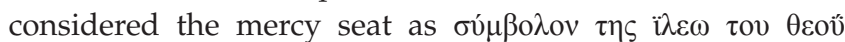
$\delta$ vvó $\mu \varepsilon \omega$ ५. $^{22}$ Bailey (2000:157) writes, 'Perhaps this shows that Philo traced the term i $\lambda \alpha \sigma \tau$ prov etymologically not to i $\lambda \alpha$ $\sigma \kappa \varepsilon \sigma \theta \alpha$ ( "to propitiate or expiate") but to i $\lambda \varepsilon \omega \varsigma$, "gracious" or "merciful"'. This understanding therefore contradicts the translation in popular English versions: 'sacrifice of atonement' (NIV, NRSV; cf. NLT) or 'propitiation' (ESV, NKJV). Only the NET translates i $\lambda \alpha \sigma \tau$ prov as 'mercy seat'. ${ }^{23}$

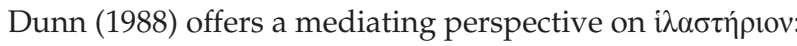

The word was probably chosen to evoke or emerged as summary of a complex of ideas ... The metaphor is different of course from the idea of 'God in Christ reconciling the world to himself' (2 Cor 5:19), but Paul could hold the two together without difficulty (2 Cor 5:21); that he can use such apparently conflicting imagery should warn us against pressing the metaphorical language for a too literal or allegorical sense. ${ }^{24}$ (p. 170)

If indeed Paul is using i $\lambda \alpha \sigma \tau$ ípıv to summarise such a complex of theological concepts, its use in Romans 3:25 could include the idea of reconciliation. ${ }^{25}$ Weiß (2014b:4) agrees that "reconciliation" as the result of propitiation is part of the complex meaning, which cannot be really expressed in one word'. Reconciliation in Romans is a key subtext and has both vertical and horizontal dimensions. In the opening three chapters, Paul presents his case that both Jews and Gentiles are sinful and have fallen short of God's righteous standard, concluding: 'We have already made the charge that Jews and Gentiles alike are all under sin. As it is written: "There is no one righteous, not even one"' (Rom 3:9-10 NIV). Thus, humanity must be reconciled to God, and faith in and of Jesus Christ is the only thing that can restore that vertical relationship. The horizontal division between Jew and Gentiles is first introduced in the rhetoric of 1:16. Commentators on Romans agree that a tension existed in the Roman church between the Gentile and Jewish believers.

22.English: 'a symbol of the gracious power of God'; cf. Philo (Fug. 100).

23.Beale (2011:488-490) likewise argues that 'mercy seat' is the best understanding of this metonym based on its 28 uses in the LXX as well as in Hebrews 9:5.

24. However, in his explanation of the text, Dunn (1988:180) drops the ambiguity suggested in his earlier discussion and uses exclusively the interpretation 'mean of expiation'. According to Wright (2016.332) Paul's the negy in Romans 3.25 is of expiation. According to Wright (2016:332), Paul's theology in Romans 3:25 is drawn from Second Temple theology with the idea of i $\lambda \alpha \sigma$ triptov representing both the meeting place of heaven and earth as well as the cleansing place for
human sin.

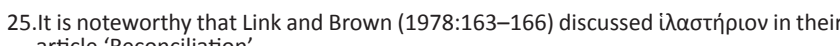
article 'Reconciliation'. 
The expulsion of some Jews by Claudius in $49 \mathrm{CE}$ including Priscilla and Aquila (Ac 18:2) left Gentile believers now in leadership roles. When these Jewish believers returned to Rome, they found a changed situation. As deSilva (2004) writes:

Both sides now had to adjust; the Jewish Christians to a church which was no longer under their direction, the Gentile Christians to a group of estranged sisters and brothers whose practices some found difficult to integrate and whose objections were difficult to understand or honor. ${ }^{26}$ (p. 601)

In addition, Paul's exhortations about Israel in chapters 9-11 serve as reconciling language not only for the world (Rom 11:15) but also for the Christian community in Rome.

\section{Paul and imperial ideology}

Whether Paul was consciously attempting to counter imperial ideology in Romans and in his other letters cannot be debated here. The minimalists ${ }^{27}$ and maximalists ${ }^{28}$ on both sides continue to argue their respective cases. As with most hermeneutical and methodological debates, there is a tendency to overstate or understate the evidence with a subsequent inability to find valid points on the other side. Indeed, each text needs to be approached in its own right to determine the legitimacy of a possible imperial reading. Does Paul use i $\lambda \alpha \sigma \tau$ ๆ́ reading? Is this another 'hidden transcript' in Romans that was intelligible to readers whom Lim (2015:5-10) thinks were first addressed in 1:18-32 and are again addressed in 13:1-7?

In his 'Response' that concludes Paul and the Roman imperial order, the Roman historian Price (2004:181) observes: 'The world of Augustan court ideology is very remote from the world of the eastern cities of the Roman Empire'. Nevertheless, he states that the gap can be lessened by finding comparable ideology articulated by an eastern province like Asia. His example is the calendar degree dating from the winter of $9 / 8$ $\mathrm{BCE}$ and issued by the koinon of Asia. In $29 \mathrm{BCE}$, the consul of Asia L. Volcacius Tullus offered a crown for whoever suggested the best way to honour the divine emperor. This prize was not awarded until 9 BCE when the proconsul Paullus Fabius Maximus suggested that the New Year based on the solar Julian calendar should begin on Augustus's birthday. The provincial calendar was thus reconfigured to 23 September, the birthday of Augustus. Fabius Maximus ordered that the edict then be erected on a stele in the temple of Rome and Augustus at Pergamum. Cooley (2012) notes that:

the koinon also decreed its own publication clause, surpassing that of the governor, in which it required that both the proconsul's edict and its own decree should be inscribed upon stelai of white marble and be set in the temples of Caesar in the cites at the head of the judicial districts. (pp. 165-166)

26.For more on this as a pastoral purpose of the letter, see Fitzmyer (1992:76-78) and Edwards (1992:10-13).

27.See, for example, Kim (2008) and Barclay (2016), especially his two final essays 'Paul, Roman religion and the emperor: Mapping the point of conflict' and 'Why the Roman empire was insignificant to Paul'.

28.See, for example, Georgi (1991), Elliott (1994; 2008a; 2008b) and the volumes edited by Horsley $(1997 ; 2000 ; 2004 ; 2008)$.
The discovery of the monument in at least four Asian cities that did not function as assize centres shows that the decree's distribution was even greater than what Cooley suggests.

The Priene version, first published in 1899, was popularised by Deissmann (1910:370-371, Figures 59-60; cf. 349, 351) in his Light from the ancient east. ${ }^{29}$ It became known as the 'good news' (cf. Mark 1:1) of Caesar because of its use of

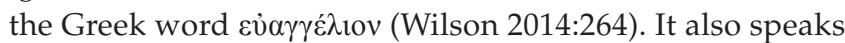
of divine providence ordering everyone's lives and 'producing Augustus for the benefit of the human race; eternal and immortal nature had devised this as the greatest possible benefaction' (Cooley 2012:165-166). Its importance was not so much religious as national and social, according to Sherk (1969):

for it was used by Rome to perpetuate and preserve a local loyalty to Rome and the emperor.... The position occupied by Augustus as emperor and god in the Greek East is nowhere else more clearly or eloquently illustrated..$^{30}$ (pp. 336-337)

Other fragments of the inscription were subsequently found in the Asian cities of Maonia, Apamea, Eumenea and Dorylaeum. ${ }^{31}$ Two stones containing much of the calendar inscription were discovered in the excavations at Metropolis around the same time as the altars (Figure 6). That Metropolis was intent on promulgating imperial ideology is reinforced by this discovery. In the same article that presented the altars to Caesar, Dreyer and Englemann (2006:175-182) also published the newly discovered version of the calendar decree from Metropolis and compared it to the Priene version. For Christians in cities like Metropolis and Ephesus, Stanton (2004:32) suggests that the inscription would contain 'an unmistakable whiff of eschatology and

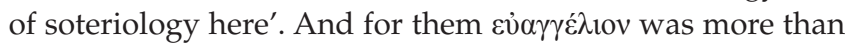
what the English word 'gospel' connotes as 'good news'.

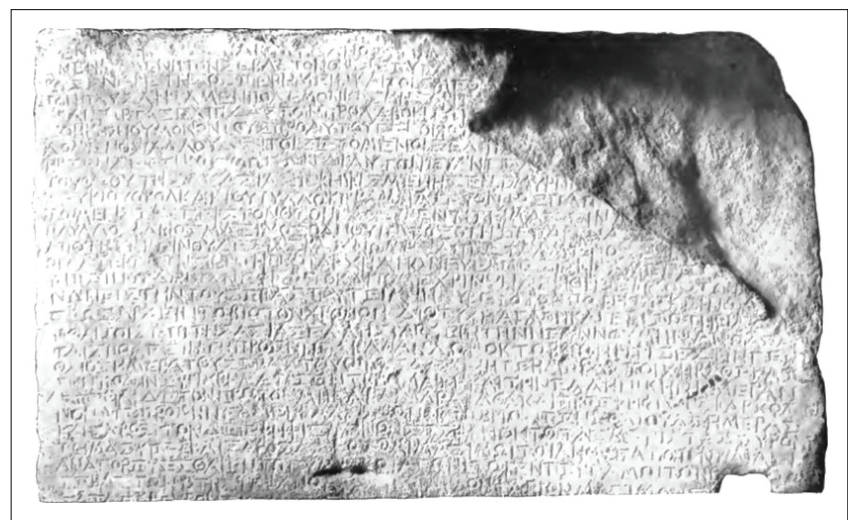

Source: Courtesy Dreyer and Engelmann

FIGURE 6: Fragment of calendar inscription from Metropolis.

29.Deissmann $(1910: 342,345)$ was among the first to call attention to the New Testament's 'strongly pronounced tone of protest against the worship of Caesar' and that Paul and the early Christians 'were familiar with the institutions and customs that the Empire had brought with it'.

30.See Thonemann (2015:140; cf. 123) for a similar assertion.

31.The serendipitous nature of the survival of ancient inscriptions is best illustrated by the numerous Graeco-Roman decrees dealing with Jewish rights cited by Josephus (Ant. 14.185-267). None of these have yet been found. For a recent discussion of Ant. 14.185-267). None of these have yet been found. For a recent discussion of
this issue of survival, see Cooley (2012:166-167), although she does not discuss the calendar decree specifically. 
According to Elliott (2008b:98), 'Such an understanding evacuates it of its political resonance. It was used ... to announce or celebrate the emperor's accession to power'. The Metropolis altars functioned similarly, for as Cooley and Salway (2012:199) suggest, 'whoever set up the altars there was actively engaging with imperial ideology, and not just copying standard ways of referring to Augustus'. The altars and the inscription served as a two-pronged declaration of this ideology.

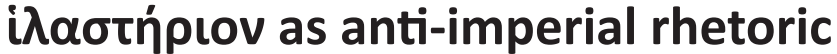 and the distribution of inscriptions}

Is there a vocabulary of anti-imperial rhetoric in Romans? Speaking in the affirmative and specifically about Paul's use

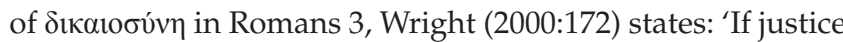
is wanted, it will be found not in the euaggelion that announces Caesar as Lord but in the euaggelion of Jesus'. Speaking in the negative, Kim (2008) responds:

Even while expounding the gospel of Jesus Christ in terms of such key concepts like 'righteousness/justice', 'peace', and 'freedom' in Rom 1-8, Paul does not make any efforts to compare the righteousness/justice, peace, and freedom of Jesus Christ with those of the Roman Empire. (p. 67 n. 1)

The former seems the preferable option here with i $\lambda \alpha \sigma \tau \eta \dot{\rho t o v}$ entering the vocabulary of anti-imperial rhetoric that includes other terms such as $\sigma \omega \tau \eta \dot{\rho} / \sigma \omega \tau \eta \rho i ́ \alpha, \dot{\varepsilon} \pi \imath \varphi \alpha ́ v \varepsilon 1 \alpha, \kappa v ́ \rho ı \varsigma$, and

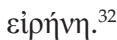

If $i \lambda \alpha \sigma \tau$ ๆ́pเov is anti-imperial rhetoric, the question might well be asked: Would recipients of Paul's letter in the Roman church recognize it? From Corinth Paul was alerting the Romans about his upcoming visit to Rome to announce the gospel message in the empire's capital (cf. Wright 2000:171). Rome was over $1600 \mathrm{~km}$ away from Metropolis. If Paul had seen the altars dedicated to Augustus while visiting Metropolis, he would have recognised i $\lambda \alpha \sigma \tau$ ń familiar from the LXX and Second Temple worship but now recast within imperial ideology. Because inter-community koinonia likely occurred between the Christians in Ephesus and Metropolis, Priscilla and Aquila might have visited the city as well (cf. Rom 16:3). Others in the Roman church who had travelled in the Greek east might also have seen the

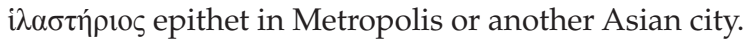

Cooley (2012:159) notes that official information was disseminated in epigraphic form in three ways: (1) specific publication for a specific audience, (2) publication of multiple copies for specific audiences and (3) universal publication. The Res Gestae exemplifies the third way with wide dissemination after its publication in Rome following Augustus's death in $14 \mathrm{CE}$. Yet throughout the empire only a few copies have been found and all in Asia Minor. ${ }^{33}$

32.For a fuller list, see Kim (2008:68); however, he denies that such a vocabulary exists.

33.In Galatia, three have been found: the complete bilingual copy on the Temple of Rome and Augustus at Ancyra and fragments at Antioch near Pisidia and Apollonia. Thonemann (2012) has recently identified a fragment in Sardis, making this the first copy found in Asia.
The calendar degree, discussed earlier, falls into category 2. The first copy was discovered in the late 19th century, while over a century of excavation has passed before the most recent copy came to light in Metropolis.

Are the two Metropolis altars with i $\lambda \alpha \sigma \tau$ ṕ the first category whose audience was meant to be specific and local? Such a conclusion is doubtful. It was more likely extraprovincial because other provinces in the Greek east like Asia and Achaia had also benefited from the largesse of Augustus after his defeat of Antony. So in other eastern cities similar altars to Augustus might have been erected, possibly even in Rome. Their sole discovery in Metropolis could just be an accident of epigraphical history. Therefore, it can be hoped that additional examples of imperial inscriptions with i $\lambda \alpha \sigma \tau$ ๆ́ will be discovered in excavations at other ancient sites.

\section{Conclusion}

Although Keegan (2014) is writing about graffiti, his point has similar application considering the purpose of the Metropolis altars:

we can focus on the dynamic process each of these graffiti displays. Specifically, we can identify and decipher the 'script' that is, a specific sequence of perception, evaluation and response - through which the data of life are processed ... The approach is cognitive rather than lexical, asking what each graffito does, and how it works socially and psychologically, rather than simply asking what it is (a question that would tend to yield lexical equivalents). (p. 3)

The altars of Metropolis functioned similarly as social and psychological expressions of the belief among the elite in Metropolis that Octavian was the divine gift of God sent to re-establish order and peace in the world through his reconciling power. Thus, it was inevitable that the imperial ideology that Octavian/Augustus was the reconciler of the world would collide with Paul's theology that Jesus Christ was in fact that reconciler. For Paul the reconciliation introduced by Jesus was not just temporal for an empire but eternal for the world (Rom 11:15).

\section{Acknowledgements Competing interests}

The author declares that he has no financial or personal relationships which may have inappropriately influenced him in writing this article.

\section{References}

Aitken, J.K., 2014, No stone unturned: Greek inscriptions and Septuagint vocabulary, Eisenbrauns, Winona Lake, IN.

Aybek, S., Meriç, A.E. \& Öz, A.K., 2009, Metropolis, an archaeological guide, Homer, Istanbul.

Bailey, D.P., 2000, 'The mercy seat: The semantics and theology of Paul's use of "hilasterion" in Romans 3:25', Tyndale Bulletin 51(1), 155-158.

Barclay, J., Pauline churches and diaspora Jews, Eerdmans, Grand Rapids, MI.

Bauer, W., Arndt, W.F., Gingrich, F.W. \& Danker, F.W., 2000, A Greek-English lexicon of the New Testament and other early Christian literature, University of Chicago Press, Chicago, IL. 
Beale, G.K., 2011, A New Testament biblical theology: The unfolding of the Old Testament in the New, Baker, Grand Rapids, MI.

Benjamin, A. \& Raubitschek, A.E., 1959, 'Arae Augusti', Hesperia 28, 65-85. http:// dx.doi.org/10.2307/147339

Chaniotis, A., Corsten, T., Stroud, R.S. \& Tybout, R.A., 2005, Supplementum Epigraphicum Graecum, vol. 55, Brill, Leiden.

Chaniotis, A., Corsten, T., Stroud, R.S. \& Tybout, R.A., 2006, Supplementum Epigraphicum Graecum, vol. 56, Brill, Leiden.

Chaniotis, A., 2012, 'Listening to stones: Orality and emotions in ancient inscriptions', in J. Davies \& J. Wilkes (eds.), Epigraphy and the historical sciences, pp. 299-328, Oxford University Press, Oxford.

Cooley, A., 2009, Res Gestae Divi Augusti: Text, translation, and commentary, Cambridge University Press, Cambridge.

Cooley, A., 2012, 'From document to monument: Inscribing Roman official documents in the Greek east', in J. Davies \& J. Wilkes (eds.), Epigraphy and the historical sciences, pp. 159-182, Oxford University Press, Oxford.

Cooley, A. \& Salway, B., 2012, 'Roman inscriptions 2006-2010', Journal of Roman Studies 103, 172-286. http://dx.doi.org/10.1017/S0075435812001074

Deissmann, A., 1910, Light from the ancient east, Hodder and Stoughton, London.

DeSilva, D., 2004, Introduction to the New Testament, IVP Academic, Downers Grove, IL.

Dreyer, B. \& Engelmann, H., 2006, 'Augustus und Germanicus im ionischen Metropolis', Zeitschrift für Papyrologie und Epigraphik 158, 175-182.

Dunn, J., 1988, Romans 1-8, Word, Waco, TX.

Edwards, J.R., 1992, Romans, Hendrickson, Peabody, MA.

Elliott, N., 1994, Liberating Paul: The justice of God and the politics of the apostle Orbis, Maryknoll, NY.

Elliott, N., 2008a, 'The apostle Paul and empire', in R.A. Horsley (ed.), In the shadow of empire: Reclaiming the Bible as a history of faithful resistance, pp. 97-116, Westminster John Knox, Louisville, KY.

Elliott, N., 2008b, The arrogance of nations: Reading Romans in the shadow of empire, Fortress, Minneapolis, MN.

Fishwick, D., 2014, 'Augustus and the cult of the emperors', Studia Historica H. ${ }^{a}$ antig. 32, 47-60.

French, D.H., 1997, 'Pre- and early Roman roads of Asia Minor. A Hellenistic stadionstone from Ephesus', Arkeoloji Dergisi 5, 189-196.

Fitzmyer, J.A., 1992, Romans, Doubleday, New York.

Friberg, T., Friberg, B. \& Miller, N.F., 2005, Analytical lexicon of the Greek New Testament, Trafford, Vancouver.

Galinsky, K., 2012, Augustus: Introduction to the life of an emperor, Cambridge University Press, Cambridge.

Georgi, D., 1991, Theocracy in Paul's practice and theology, Fortress, Minneapolis, MN.

Goldsworthy, A., 2014, Augustus: First emperor of Rome, Yale University Press, New Haven, CT.

Horsley, R.A. (ed.), 1997, Paul and empire: Religion and power in Roman imperial society, Trinity Press International, Harrisburg, PA.

Horsley, R.A. (ed.), 2000, Paul and politics: Ekklesia, Israel, imperium, interpretation, Trinity Press, International, Harrisburg, PA.

Horsley, R.A. (ed.), 2004, Paul and the Roman imperial order, Trinity Press International, Harrisburg, PA.

Horsley, R.A. (ed.), 2008, In the shadow of empire: Reclaiming the Bible as a history of faithful resistance, Westminster John Knox, Louisville, KY.

Jewett, R., 2007, Romans, Fortress, Minneapolis, MN.
Jones, C.P., 1999, 'Atticus in Ephesos', Zeitschrift für Papyrologie und Epigraphik 124, 89-94.

Keegan, P. 2014, Graffiti in antiquity, Routledge, London.

Kim, S., 2008, Christ and Caesar: The Gospel and the Roman Empire in the writings of Paul and Luke, Eerdmans, Grand Rapids, MI.

Lim, S.U., 2015, 'A double-voiced reading of Romans 13:1-7 in light of the imperial cult', HTS Teologiese Studies/Theological Studies 71(1), Art. \#2475, 1-10. http:// dx.doi.org/10.4102/hts.v71i1.2475

Link, H.-G. \& Brown, C., 1978, 'Reconciliation', in C. Brown (ed.), The new international dictionary of New Testament theology, vol. 3, pp. 145-176, Zondervan, Grand dictionary of
Rapids, MI.

Lust, J., Eynikel, E. \& Hauspie, K., 2004, Greek-English lexicon of the Septuagint, rev. edn., American Bible Society, New York.

Magie, D., 1950, Roman rule in Asia Minor, Princeton University Press, Princeton, NJ.

McLean, B., 2002, An introduction to Greek epigraphy of the Hellenistic and Roman periods from Alexander the Great down to the reign of Constantine (323 B.C.-A.D. 337), University of Michigan Press, Ann Arbor, MI.

Meriç, R., 2004, Metropolis: City of the mother goddess, Philip Morris, Istanbul.

Price, S.R.F., 2004, 'Response', in R.A. Horsley (ed.), Paul and the Roman imperial order, pp. 175-183, Trinity Press International, Harrisburg, PA.

Punt, J., 2012, 'Empire and New Testament texts: Theorising the imperial, in subversion and attraction', HTS Teologiese Studies/Theological Studies 68(1), Art. \#1182, 1-11, http://dx.doi.org/10.4102/hts.v68i1.1182

Ramsay, W.M., 1898, 'Phrygia', in J. Hastings (ed.), Hastings dictionary of the Bible, 5 vols., T \& T Clark, Edinburgh.

Ramsay, W.M., 1994, The letters to the seven churches, updated edn., Hendrickson, Peabody, MA.

Scheid, J., 2009, 'To honour the princeps and venerate the gods: Public cult, neighbourhood cults, and imperial cult in Augustan Rome', in J.C. Edmondson neighbourhood cults, and imperial cult in Augustan Rome', in J.C. Edr.
(ed.), Augustus, pp. 275-309, Edinburgh, University Press, Edinburgh.

Schnabel, E., 2004, Early Christian mission, 2 vols., InterVarsity, Downers Grove.

Schreiber, S., 2006, 'Das Weihegeschenk Gottes. Eine Deutung des Todes Jesu in Röm 3,25', Zeitschrift für die neutestamentliche Wissenschaft 97, 88-110.

Sherk, R.K., 1969, Roman documents from the Greek east, Johns Hopkins, Baltimore, $\mathrm{MD}$

Stanton, G.N., 2004, Jesus and the Gospel, Cambridge University Press, Cambridge.

Talbert, R.J.A., 2000, The Barrington atlas of the Greek and Roman world, Princeton University Press, Princeton, NJ.

Thonemann, P., 2012, 'A copy of Augustus' Res Gestae at Sardis', Historia 61(3), 282-288.

Thonemann, P., 2015, 'The calendar of the Roman province of Asia', Zeitschrift für Papyrologie und Epigraphik 196, 123-141.

Weiß, A., 2014a, 'Christus Jesus als Weihegeschenk oder Sühnemal? Anmerkungen zu einer neueren Deutung von hilasterion (Röm 3,25) samt einer Liste der epigraphischen Belege', Zeitschrift für die neutestamentliche Wissenschaft 105 294-302.

Weiß, A., 2014b, 'Augustus as reconciler?', Paper presented on 1 October 2014 at the Conference 'Augustus from a Distance', University of Sydney.

Wilson, M., 2014, Biblical Turkey, 3rd edn., Ege, Istanbul.

Wright, N.T., 2000, 'Paul's Gospel and Caesar's Empire', in R.A. Horsley (ed.), Paul and politics: Ekklesia, Israel, imperium, interpretation, Trinity Press International, Harrisburg, PA.

Wright, N.T. 2016, The day the revolution began: Reconsidering the meaning of Jesus's crucifixion, HarperOne, San Francisco, CA.

Zanker, P., 1990, The power of images in the age of Augustus, University of Michigan Press, Ann Arbor, MI. 